\title{
Evaluation of Antibacterial Properties of Leaves and Barks of Rhizophora stylosa against Gram-Positive and Gram- Negative Organisms
}

\author{
Natesan Gopal ${ }^{1 *}$, Jane Ekegbu², Christina Parvinder Kaur ${ }^{2}$, Ponnaiah Paulraj², \\ Raji P. ${ }^{3}$ and Karanam Sai Bhavya ${ }^{3}$
}

${ }^{1}$ Faculty of Pharmacy, MAHSA University, Jalan SP 2, Bandar Saujana Putra, 42610 Jenjarum Selangor, Malaysia. ${ }^{2}$ Department of Biomedical Sciences, Faculty of Medicine, MAHSA University, Jalan SP 2, Bandar Saujana Putra,42610 Jenjarum Selangor, Malaysia. ${ }^{3}$ Department of Biotechnology, Sathyabama Institute of Science and Technology, JeppiaarNagar, Rajiv Gandhi Salai, Chennai - 600 119, India.

\begin{abstract}
The number of multi-drug resistant microbial strains and the appearance of strains with reduced susceptibility to antibiotics are continuously increasing and it has been attributed to indiscriminate use of broad spectrum antibiotics. It is common sense that the scarcely explored extensive Malaysian biodiversity would yield countless opportunities to find plant species potentially secreting metabolites, exhibiting antimicrobial activity, among other medicinal properties. In this study leaves and barks of Rhizophora stylosa were collected and extracted using various organic solvents such as petroleum ether, chloroform and methanol. These crude extracts were further evaluated for antimicrobial properties by different methods against Staphylococcus aureus, Staphylococcus epidermidis, Streptococcus pyogenes, Escherichia coli, Klebsiella pneumoniae and Pseudomonas aueroginosa. The bark extracts were more potent than leaf extracts of $R$. stylosa. The chloroform extracts were found to have the highest antimicrobial activity with an MIC of $0.1 \mathrm{mg} / \mathrm{ml}$ and $\mathrm{MBC}$ of $6.3 \mathrm{mg} / \mathrm{ml}$.
\end{abstract}

Keywords: Leaves, Bark, antimicrobial properties.

\footnotetext{
*Correspondence: gopal@mahsa.edu.my

(Received: 18 March 2019; accepted: 01 May 2019)

Citation: Natesan Gopal, Jane Ekegbu, Christina Parvinder Kaur, Ponnaiah Paulraj, Raji P. and Karanam Sai Bhavya, Evaluation of Antibacterial Properties of Leaves and Barks of Rhizophora Stylosa against Gram-Positive and Gram- Negative Organisms, J Pure Appl Microbiol., 2019; 13(2): 957-965. doi: 10.22207/JPAM.13.2.32

(c) The Author(s) 2019. Open Access. This article is distributed under the terms of the Creative Commons Attribution 4.0 International License which permits unrestricted use, sharing, distribution, and reproduction in any medium, provided you give appropriate credit to the original author(s) and the source, provide a link to the Creative Commons license, and indicate if changes were made.
} 


\section{INTRODUCTION}

Infectious diseases cause a serious public health issue which remain a major threat to the whole world (Jacoby et al., 2010; Fonkwo et al., 2008).Currently, multi drug resistance become a major problem due to the usage of various antimicrobial drugs that necessitated the search for alternative antimicrobial agents from natural resources (Sasidharan et al., 2011; Saad et al., 2011). It is well known that plants are the rich source of active compounds which inhibit growth of several microorganisms (Saad et al., 2012). Malaysia is one of the 12 mega diversity centres of the world and is rich in plant genetic diversity with many of the plants used for medicinal purposes (Nasir and Yusmah, 2007). Burkill (1996) in his extensive compilation of the economic products of the Malay Peninsular, recorded not less than 1,300 plants have been used in traditional medicine. Over the years, there has been an increasing demand for medicinal plants within Malaysia for use in folk medicine. (Jantan, 2004).

Mangroves were known to possess high medicinal values and are used for the treatment of various diseases (Patra \& Thatoi, 2011). They were also found to be the rich source for their novel products due to the presence of various active antimicrobial compounds (Bhimba et al., 2010). The metabolites isolated from these plants are found to be biologically active when compared to others which gets activated after the tissue damage or pathogen attack (Ncube et al., 2008). Mangroves are known to play a vital role in shoreline protection, enhancement of water quality in nearshore environments and in supporting estuarine and marine food chains. An alkaloid isolated from mangrove plant Fagara zanthoxyloides was found to pocess antibacterial activity (Bandaranayake 2002). Xanthopen extracted from $C$. inophyllum was found to have anti-viral property (Patra \& Thatoi, 2011). Similar results were seen with the extracts of Pongamia pinnata against simian and human immunodeficiency virus (Premanathan et al. 1999a, b). The derivative of flavonol extracted from rhizospora species were found to pocess strong antioxidant property. Gedunin a compound isolated from mangrove plants were found to have anti-cancer activity (Uddin et al. 2007). The stem and leaf extracts of $E$. agallocha displayed antimicrobial activity. (Masuda et al. 1999; Konishi et al. 1998). The bark of Xylocarpus moluccensis was found to show antimicrobial properties against wide range of micro-organisms (Nathan et al. 2005; Omar et al. 2003; Jun et al. 2008). The bark and leaves of few mangrove plants displayed species specific activity against virulent microorganisms (Choudhury et al. 2005). An ester isolated from $H$. littoralis known to pocess potent antifungal property (Bandaranayake 2002).

Many mangrove plants especially Rhizophoraceae species show strong antimicrobial properties (Patra \& Thatoi, 2011). The plants of Rhizophora species grows in coastal regions in limited areas in Malaysia, Indonesia and Australia and they are widespread throughout most tropic coastal areas of the western pacific region to east Africa (Nasir and Yusmah, 2007). It consists of three species namely $R$. mucronata, $R$. stylosa, and $R$. apiculata and two hybrids, $R$. $x$ lamarckii and $R . x$ annamalai. It has been reported that some extracts of Rhizophora species have wide variety of pharmacological properties like antifungal (Caceres et al., 1993), antibacterial (Melchor et al., 2001), anti-inflammatory (Marrero et al., 2006), antiulcer (Berenguer et al., 2006), antiseptic (Laphookhieo et al., 2004) and efficacy in wound healing (Fernandez et al., 2002). Although abundant literature on the medicinal properties of plants exists, some species of the myriads of mangrove plants remain unexplored. Hence this study is an attempt to explore the antibacterial properties of Rhizophora stylosa leaves and bark extracts against Gram positive and Gram negative bacteria.

\section{MATERIALS AND METHOD}

Petroleum ether, Ethyl acetate, chloroform, methanol, mannitol salt agar, cetrimide agar, MacConkey agar, blood agar, Mueller-Hinton Agar (MHA), Mueller-Hinton Broth (MHB), Dimethyl Sulfoxide (DMSO). All the chemicals used in this course of study were of analytical grade obtained from Sigma-Aldrich, HiMedia and Becton Dickinson and Company. The barks and leafs of $R$. stylosa were collected from Bagan Lalang Beach, Sepang, Selangor, Malaysia $\left(2^{\circ} 35^{\prime} \mathrm{N}, 101^{\circ} 41^{\prime} \mathrm{E}\right)$ and were identified 
and authenticated by the Herbarium Department of the Forest Reserve Institute of Malaysia (FRIM) (Ref. No. FRIM394/490/5/17(90)

Collection of Plant Materials

The barks and leafs of $R$. stylosa were collected from Bagan Lalang Beach, Sepang, Selangor, Malaysia $\left(2^{\circ} 35^{\prime} \mathrm{N}, 101^{\circ} 41^{\prime} \mathrm{E}\right)$ as shown in Fig. 1,2,3. and were identified and authenticated by the Herbarium Department of the Forest Reserve Institute of Malaysia (FRIM)

\section{Pre-Treatment of Plant Materials}

The collected leaves and barks were washed thoroughly and shade dried at room temperature which were homogenized further to get a fine powder.

\section{Preparation of Crude Extracts}

The extraction was done by using various solvents such as petroleum ether, chloroform, methanol using Soxhlet apparatus method (Negi et al., 2001). 100g of plant powder was subjected to Soxhlet apparatus with $500 \mathrm{ml}$ of solvents for $48 \mathrm{hrs}$. After the extraction the solvents were removed and crude extracts were dried and stored in desiccators. The obtained powder was further diluted with DMSO in order to prepare various concentrations i.e $12.5 \mathrm{mg} / \mathrm{mL}, 25 . \mathrm{mg} / \mathrm{mL}$, and $50 \mathrm{mg} / \mathrm{mL}$.

\section{Bioactivity studies of Crude Extracts Preparation of Stadardized Inoculum}

Six microbial strains consisting of both gram positive and gram negative bacteria namely Staphylococcus aureus, Staphylococcus epidermidis, Streptococcus pyogenes, Escherichia coli, Klebsiella pneumoniae and Pseudomonas aueroginosa were used in this study. ATCC numbers of these strains was mentioned in Table 1. The selective media used to obtain these strains were mannitol salt agar (for mannitol-fermenting S. aureus and S. epidermidis), blood agar (for $S$. pyogenes), cetrimide agar (for $P$. aeroginosa), and Mac Conkey agar (for E. coli and K. pneumoniae). These cultures were further maintained by culturing in nutrient agar slants at $4^{\circ} \mathrm{C}$ for 10 days Pure colonies of test bacterium were inoculated into fresh Mueller-Hinton Broth (MHB) from a culture in Mueller-Hinton Agar (MHA). The inoculum was standardized by comparing to 0.5 McFarland Turbidity standards to a concentration of $1-2$ x $108 \mathrm{CFU} / \mathrm{ml}$ (Baron et al., 1994; Saeed \& Tariq, 2005)

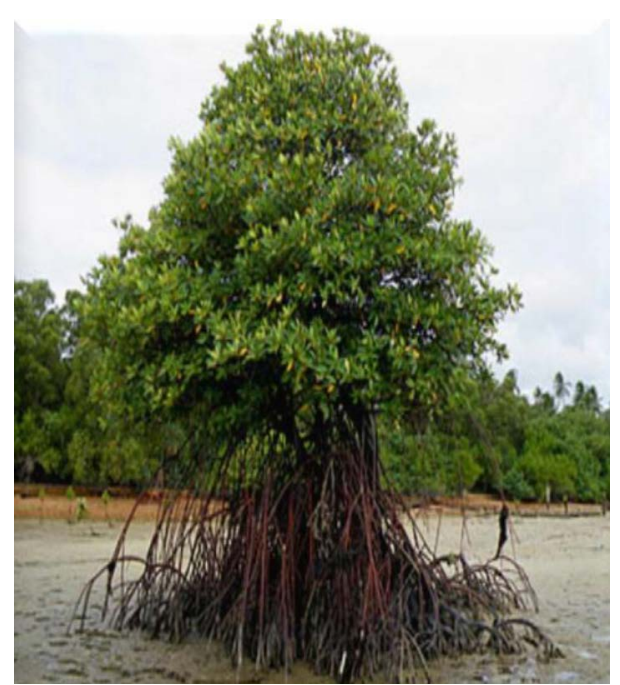

Fig. 1. Rhizophora stylosa Plant

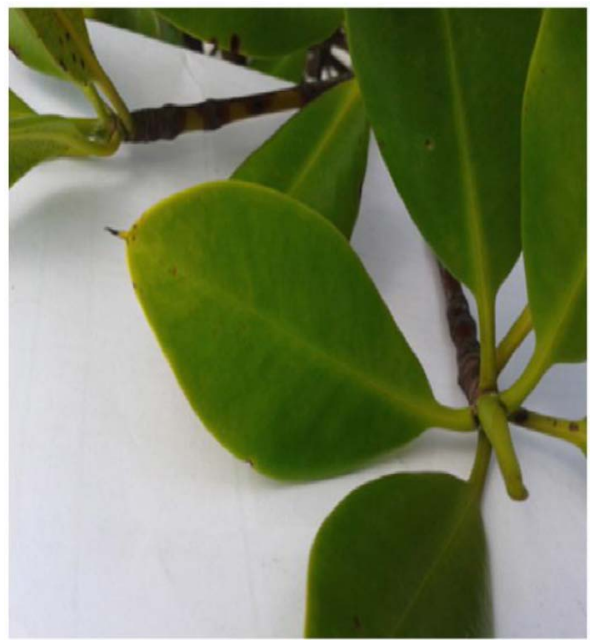

Fig. 2. Rhizophora stylosa Leaves

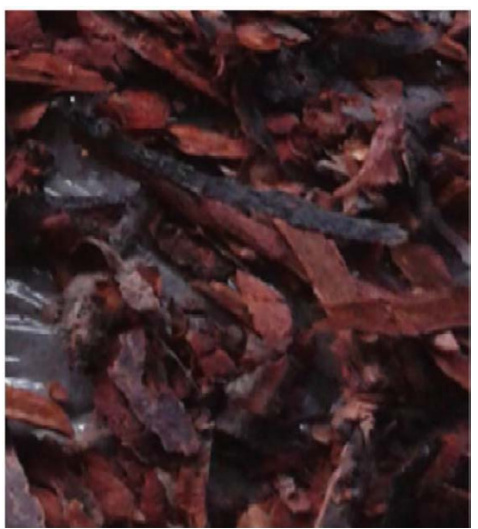

Fig. 3. Rhizophora stylosa Bark 
Table 1. Bacterial stains with ATCC number and Gram status

\begin{tabular}{lcc}
\hline Bacterial Strain & $\begin{array}{c}\text { ATCC Strain } \\
\text { Number }\end{array}$ & $\begin{array}{c}\text { Gram } \\
\text { Status }\end{array}$ \\
\hline Staphylococcus aureus & 29213 & $\begin{array}{c}\text { Gram } \\
\text { positive } \\
\text { Gram } \\
\text { positive } \\
\text { Gram }\end{array}$ \\
Streptococcus pyogenes & 19615 & $\begin{array}{c}\text { positive } \\
\text { Gram } \\
\text { negative } \\
\text { Gram }\end{array}$ \\
Klebsiella pneumonia & 13863 & $\begin{array}{c}\text { negative } \\
\text { Gram }\end{array}$ \\
Pseudomonas aeruginosa & 27853 & \begin{tabular}{c} 
negative \\
\hline
\end{tabular} \\
\hline
\end{tabular}

\section{Antimicrobial Assay by Agar Well Diffusion Method}

Agar well diffusion technique was carried out in Muller-Hinton Agar plates as described by Perez et al. (1990). $50 \mu \mathrm{l}(0.05 \mathrm{ml})$ of standardized bacterial suspension was spread over the plate using a cotton swab and wells of $7 \mathrm{~mm}$ diameter were made using standard well borer. $50 \mu \mathrm{l}$ of each extract were added to well where DMSO and Norfloxacin drug was used as negative and positive drug respectively. These inoculated plates were incubated at $37^{\circ} \mathrm{C}$ for $24 \mathrm{~h}$. All the experiments were carried out in triplicates and the inhibition zone was observed.

Antimicrobial Assay by Minimum Inhibitory Concentration Method

The minimum inhibitory concentration (MIC) of the extracts was evaluated in the 96-well microtiter plate in triplicate using the broth microdilution method. It was done as described by Saad et al(2014). A two fold dilution was made by mixing
MHB with a stock solution of extract. $0.1 \mathrm{~mL}$ of MHB was added to all wells and $100 \mu \mathrm{L}$ of plant extract was added to the first well which gives a concentration of $50 \mathrm{mg} / \mathrm{mL}$ and serial dilution was done in order to obtain $0.1 \mathrm{mg} / \mathrm{mL}$ A standardized bacterial suspension of the test organism with concentration of $1-2 \times 10^{8} \mathrm{CFU} / \mathrm{ml}$ (0.5 McFarland standard) was prepared and diluted. $5 \mu$ of this suspension was added to each well which gives a concentration of $5 \times 10^{5} \mathrm{CFU} / \mathrm{ml}$. Two control wells were also used where bacterial suspension and $\mathrm{MH}$ broth were taken as positive and negative control. These plates were incubated at $37^{\circ} \mathrm{C}$ for 24 $\mathrm{h}$ and the absorbance was taken at $630 \mathrm{~nm}$ using ELISA tray reader.

\section{Antimicrobial Assay by Minimum Bactericidal Concentration Method}

The MBC of the extracts was determined by using the plating method. A loop was inserted into the wells of the overnight incubated microtitre plates from column 1 to 10 of MIC assay plates and streaked onto Mueller-Hinton ( $\mathrm{MH}$ ) agar plates. The plates were incubated at $37^{\circ} \mathrm{C}$ for $24 \mathrm{~h}$ and the growth of micro organisms was observed on plate. The $\mathrm{MBC}$ was recorded as the lowest concentration of the extracts that did not show any bacterial growth.

\section{Statistical Analysis}

All the data obtained were analysed using the statistical software, Minitab ${ }^{\mathrm{TM}}$, which performs a multifactorial ANOVA (analysis of variation) for the comparison of different plant parts in relation to different solvent systems and different organisms.

\section{RESULTS AND DISCUSSION \\ Preparation of Crude Extracts}

The crude extracts were prepared

Table 2. Percentage yield of crude extracts of $R$. stylosa leaves and barks

\begin{tabular}{lcccc}
\hline Plant Part & $\begin{array}{c}\text { Organic } \\
\text { Extract }\end{array}$ & $\begin{array}{c}\text { Amount } \\
\text { of Powder } \\
\text { Extracted (g) }\end{array}$ & $\begin{array}{c}\text { Amount } \\
\text { of Extract } \\
\text { Obtained }(\mathrm{g})\end{array}$ & \% yield \\
\hline LEAVES & $\mathrm{PE}$ & 800 & 64.8 & 8.1 \\
& $\mathrm{CL}$ & 800 & 60.0 & 7.5 \\
\multirow{3}{*}{ BARKS } & $\mathrm{MT}$ & 800 & 169.6 & 21.2 \\
& $\mathrm{PE}$ & 1120 & 70.6 & 6.3 \\
& $\mathrm{CL}$ & 1120 & 142.2 & 12.7 \\
& $\mathrm{MT}$ & 1120 & 361.8 & 32.3 \\
\hline Journal of Pure and Applied Microbiology & \multicolumn{2}{c}{960}
\end{tabular}


using various solvents such as petroleum ether, Chloroform and methanol by soxhlet method. The percentage of yield was calculated and tabulated in Table 2. The methanolic extracts of both the extracts was showing the maximum yield percentage followed by chloroform and petroleum ether.

\section{Bioactivity Studies of Crude Extracts}

Mangrove plants like Rhizospira species were reported to have various bioactivities like antibacterial,, antiviral, antifungal and anti-inflammatory properties. (Laphookhieo et al., 2004). Hence this study mainly focuses on evaluation of antibacterial properties of Rhizophora stylosa against various species of gram positive and gram negative bacteria.

Table 3. Zone of Inhibition of Plant Extracts of Rhizophora stylosa

\begin{tabular}{|c|c|c|c|c|c|c|c|c|c|}
\hline \multirow{2}{*}{$\begin{array}{l}\text { Bacteria } \\
\text { Strain }\end{array}$} & \multicolumn{3}{|c|}{ Petroleum Ether } & \multicolumn{3}{|c|}{ Chloroform } & \multicolumn{3}{|c|}{ Methanol } \\
\hline & $\begin{array}{c}12.5 \\
\mathrm{mg} / \mathrm{mL}\end{array}$ & $\begin{array}{c}25 \\
\mathrm{mg} / \mathrm{mL}\end{array}$ & $\begin{array}{c}50 \\
\mathrm{mg} / \mathrm{mL}\end{array}$ & $\begin{array}{c}12.5 \\
\mathrm{mg} / \mathrm{mL}\end{array}$ & $\begin{array}{c}25 \\
\mathrm{mg} / \mathrm{mL}\end{array}$ & $\begin{array}{c}50 \\
\mathrm{mg} / \mathrm{mL}\end{array}$ & $\begin{array}{c}12.5 \\
\mathrm{mg} / \mathrm{mL}\end{array}$ & $\begin{array}{c}25 \\
\mathrm{mg} / \mathrm{mL}\end{array}$ & $\begin{array}{c}50 \\
\mathrm{mg} / \mathrm{mL}\end{array}$ \\
\hline S. aureus & $8.2 \pm 0.3$ & $8.7 \pm 0.3$ & $10 \pm 0.5$ & $8.7 \pm 0.3$ & $9.8 \pm 0.8$ & $11.3 \pm 1.2$ & $8.7 \pm 0.3$ & $8.8 \pm 0.3$ & $10.2 \pm 0.3$ \\
\hline $\begin{array}{l}\text { S. } \\
\text { epidermidis }\end{array}$ & $8.5 \pm 0.5$ & $9.5 \pm 0.9$ & $10.3 \pm 0.3$ & $8.8 \pm 0.3$ & $9.3 \pm 0.6$ & $12 \pm 1.0$ & $8.7 \pm 0.3$ & $8.8 \pm 0.3$ & $9.2 \pm 0.8$ \\
\hline S. pyogenes & $8.5 \pm 0.5$ & $9.3 \pm 0.8$ & $9.8 \pm 0.3$ & $8.8 \pm 0.6$ & $9.2 \pm 0.3$ & $11.3 \pm 0.6$ & $8.3 \pm 0.3$ & $9.0 \pm 0.5$ & $9.2 \pm 0.8$ \\
\hline E. coli & $10.7 \pm 0.3$ & $13.5 \pm 0.9$ & $15.8 \pm 0.3$ & $11.3 \pm 0.3$ & $12.3 \pm 0.6$ & $16.5 \pm 0.5$ & $9.7 \pm 0.6$ & $13.3 \pm 0.3$ & $13.7 \pm 0.6$ \\
\hline $\begin{array}{l}\text { K. } \\
\text { pneumonia }\end{array}$ & $11.7 \pm 1.2$ & $12 \pm 1.0$ & $13 \pm 0.5$ & $9.7 \pm 1.2$ & $9.8 \pm 0.8$ & $11.3 \pm 0.6$ & $10.7 \pm 0.3$ & $10.8 \pm 0.3$ & $11.7 \pm 0.6$ \\
\hline $\begin{array}{l}P . \\
\text { aeroginosa }\end{array}$ & $15.5 \pm 0.9$ & $15.8 \pm 0.8$ & $18.3 \pm 0.6$ & $16.3 \pm 0.6$ & $18.2 \pm 1.6$ & $19.7 \pm 0.6$ & $15.3 \pm 0.6$ & $16.8 \pm 0.3$ & $17.2 \pm 0.3$ \\
\hline S. aureus & $12.5 \pm 0.5$ & $13.7 \pm 1.2$ & $14.3 \pm 1.2$ & $13.8 \pm 0.3$ & $14.5 \pm 0.5$ & $15.7 \pm 1.5$ & $13.2 \pm 0.8$ & $13.7 \pm 1.2$ & $14.5 \pm 1.3$ \\
\hline $\begin{array}{l}\text { S. } \\
\text { epidermidis }\end{array}$ & $13.8 \pm 0.8$ & $15 \pm 0$ & $15.5 \pm 0.5$ & $13.7 \pm 0.6$ & $15 \pm 1.0$ & $15.8 \pm 0.3$ & $16.3 \pm 0.5$ & $17.3 \pm 0.3$ & $19.3 \pm 0.6$ \\
\hline S. pyogenes & $13.5 \pm 0.5$ & $14.5 \pm 0.3$ & $14.0 \pm 0.3$ & $12.5 \pm 0.3$ & $13.0 \pm 0.3$ & $14.0 \pm 1.2$ & $12.5 \pm 0.5$ & $13.7 \pm 1.2$ & $13.7 \pm 0.6$ \\
\hline E.coli & $15.3 \pm 0.6$ & $16.5 \pm 0.5$ & $17.2 \pm 0.3$ & $16.7 \pm 0.6$ & $17.5 \pm 0.5$ & $18.5 \pm 0.5$ & $13.3 \pm 0.6$ & $14.8 \pm 0.3$ & $16.2 \pm 0.3$ \\
\hline $\begin{array}{l}\text { K. } \\
\text { pneumonia }\end{array}$ & $11.3 \pm 0.6$ & $12.3 \pm 0.6$ & $13.3 \pm 0.3$ & $10.7 \pm 0.6$ & $13.3 \pm 0.3$ & $13.7 \pm 0.6$ & $14.3 \pm 0.6$ & $15.3 \pm 0.6$ & $16.7 \pm 0.6$ \\
\hline $\begin{array}{l}P . \\
\text { aeroginosa }\end{array}$ & $10.5 \pm 0.5$ & $13.2 \pm 1.4$ & $13.3 \pm 1.5$ & $11.3 \pm 0.3$ & $12.7 \pm 1.2$ & $16.2 \pm 1.0$ & $11.3 \pm 0.6$ & $13.7 \pm 0.3$ & $14.3 \pm 1.2$ \\
\hline
\end{tabular}

Zone of Inhibition (mm); LEAVES (mean \pm S.D)

\section{Antimicrobial Assay by Agar Well Diffusion Method}

The antibacterial assay was done by agar well diffusion method and zone of inhibition was measured in triplicates and expressed as mean zone of inhibition (in $\mathrm{mm}$ ) \pm standard deviation as shown in Table 3 . The extracts of various concentrations 12.5, 25 and $50 \mathrm{mg} / \mathrm{ml}$ were tested against Gram-positive bacteria (Staphylococcus aureus, Staphylococcus epidermidis, and Streptococcus pyogenes) and Gram-negative bacteria (Escherichia coli, Klebsiella pneumonia, Pseudomonas aeruginosa). The zone of inhibition of leaf extracts against gram positive bacteria were ranged between 8 and 12,11 and 19 for gram negative bacteria whereas the zone of inhibition of bark extracts were in range of 11 to 19 in both gram positive and gram negative bacteria. Among all the leaf extracts the chloroform extracts showed the maximum zone of inhibition against gram negative bacteria. The maximum zone of inhibition for leaf extracts was seen in chloroform extract against gram negative bacteria Pseudomonas aeruginosa, whereas the maximum zone for bark extracts is seen in chloroform extracts against gram positive bacteria 
S. epidermidis and $S$. aureus which is in contrast with leaf extracts. Overall the highest zone was observed in bark extracts which is similar with the reports of tannin extracted from bark of Rhizospora species (Lim et al., 2006). The results also showed that these extracts act in dose dependent manner as the increase in zone was seen with increase in concentration from 12.5 to $50 \mathrm{mg} / \mathrm{mL}$.

\section{Antimicrobial Assay by Minimum Inhibitory Concentration Method}

The minimum inhibitory concentration was evaluated by micro dilution method and the results were interpreted and tabulated in Table 5. The MIC of petroleum ether and chloroform extracts were found to be less whereas maximum MIC was observed in methanol extracts in both the cases. The MIC of petroleum ether were found to be in the range of 0.2 to $0.8 \mathrm{mg} / \mathrm{ml}$ for leaves and $<0.1 \mathrm{mg} / \mathrm{ml}$ and $0.2 \mathrm{mg} / \mathrm{ml}$ in case of barks whereas chloroform extracts were ranging between 0.1 to $1.6 \mathrm{mg} / \mathrm{ml}$ and $<0.1 \mathrm{mg} / \mathrm{ml}$ for leaves and barks respectively. Hence among all the Chloroform extracts of bark extracts gave the least MIC against both gram positive and negative bacteria except $P$. aeruginosa which indicates that they are more effective towards selected bacteria when compared to other extracts. The bark extracts were found to exhibit higher antibacterial properties compared to the leaf extracts. This effect is likely due to the presence of different active ingredients and plant phytochemicals in bark extracts compared to leaf extracts (Courtois et al., 2012).

Table 4. Zone of Inhibition of Norfloxacin

\begin{tabular}{|c|c|c|c|}
\hline \multicolumn{4}{|c|}{ Zone of Inhibition (mm) } \\
\hline \multicolumn{2}{|c|}{ Leaves } & \multicolumn{2}{|c|}{ Barks } \\
\hline $\begin{array}{l}\text { Bacteria } \\
\text { Strain }\end{array}$ & $\begin{array}{l}\text { Norfloxacin } \\
(400 \mathrm{ng} / \mathrm{ml})\end{array}$ & $\begin{array}{l}\text { Bacteria } \\
\text { Strain }\end{array}$ & $\begin{array}{l}\text { Norfloxacin } \\
\text { (400 ng/ ml) }\end{array}$ \\
\hline S. aureus & $23.8 \pm 0.2$ & S. aureus & $24.3 \pm 0.1$ \\
\hline S. epidermidis & $22.2 \pm 0.1$ & S. epidermidis & $21.9 \pm 0.3$ \\
\hline S. pyogenes & $15.2 \pm 0.2$ & S. pyogenes & $14.8 \pm 0.2$ \\
\hline E. coli & $20.1 \pm 0.3$ & E. coli & $19.6 \pm 0.1$ \\
\hline K. pneumonia & $14.7 \pm 0.1$ & K. pneumonia & $14.2 \pm 0.2$ \\
\hline P. aeroginosa & $21 \pm 0.2$ & P. aeroginosa & $20.7 \pm 0.1$ \\
\hline
\end{tabular}

Table 5. MIC of Plant Extracts of Rhizophora stylosa

\begin{tabular}{|c|c|c|c|c|c|c|}
\hline \multirow{2}{*}{$\begin{array}{l}\text { Bacterial } \\
\text { Strain }\end{array}$} & \multicolumn{3}{|c|}{$\mathrm{MIC}(\mathrm{mg} / \mathrm{ml})$} & \multicolumn{3}{|c|}{$\mathrm{MBC}(\mathrm{mg} / \mathrm{ml})$} \\
\hline & PE & $\mathrm{CL}$ & MT & $\mathrm{PE}$ & $\mathrm{CL}$ & MT \\
\hline \multicolumn{7}{|c|}{ LEAVES } \\
\hline S. aureus & 0.2 & 0.2 & 1.6 & 25 & 12.5 & 25 \\
\hline S. epidermidis & 0.8 & 0.1 & 1.6 & 25 & 25 & 25 \\
\hline S. pyogenes & 0.8 & 0.8 & 3.2 & 25 & 12.5 & 25 \\
\hline E. coli & 0.2 & 0.2 & 6.3 & 50 & 12.5 & 25 \\
\hline K. pneumonia & 0.8 & 1.6 & 6.3 & 50 & 6.3 & 12.5 \\
\hline P. aeruginosa & 0.2 & 0.2 & 6.3 & 25 & 12.5 & 12.5 \\
\hline \multicolumn{7}{|c|}{ BARKS } \\
\hline S. aureus & $<0.1$ & $<0.1$ & 0.4 & 0.8 & 0.8 & 0.8 \\
\hline S. epidermidis & 0.1 & $<0.1$ & 0.8 & 6.3 & 0.8 & 1.6 \\
\hline S. pyogenes & 0.2 & 0.1 & 0.2 & 12.5 & 12.5 & 12.5 \\
\hline E. coli & 0.2 & $<0.1$ & 0.1 & 25 & 12.5 & 12.5 \\
\hline K. pneumonia & 0.2 & $<0.1$ & 1.6 & 3.2 & 1.6 & 1.6 \\
\hline P. aeruginosa & 0.2 & 0.2 & 0.4 & 6.3 & 12.5 & 6.3 \\
\hline
\end{tabular}

Antimicrobial Assay by Minimum Bactericidal Concentration Method

The minimum bactericidal concentration assay was carried out to determine the ability of the extracts to kill the microorganisms completely. This test enabled the determination of the viability of the organisms within the medium at various concentrations of given extracts. The MBC was taken as the lowest concentration of extracts from the MIC assay which inhibited the growth of microorganism when subcultured onto MHA plates. The bactericidal activity was found to be maximum for chloroform extracts of leaves when compared with petroleum ether and methanol. The activity of both petroleum ether and methanol extracts was found to be similar with a dosage of $25 \mathrm{mg} / \mathrm{ml}$. The bark extracts followed the similar pattern with leaf extracts. 


\section{Statistical Analysis}

This analysis showed a statistical significance as the $p$-value was less than 0.05 , thus indicating that both parts of $R$. stylosa plant (leaves and barks) and the different solvent systems (petroleum ether, methanol and chloroform extracts) (Fig. 4) had significant effect on the antibacterial properties exerted against both Gram-positive and Gram-negative bacteria (Fig. 5).

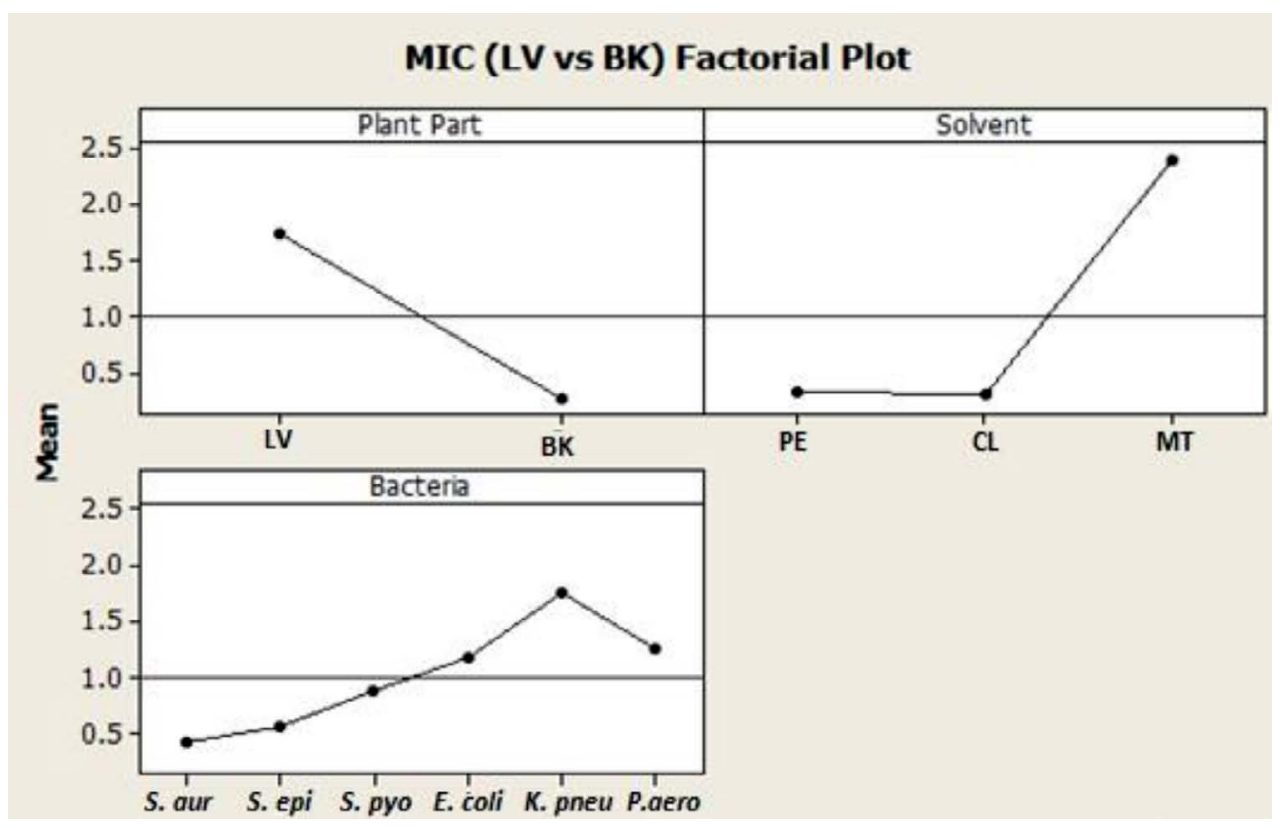

Fig. 4. Plot of multifactorial ANOVA analysis of MIC comparing plant parts, solvent systems and bacterial strains.

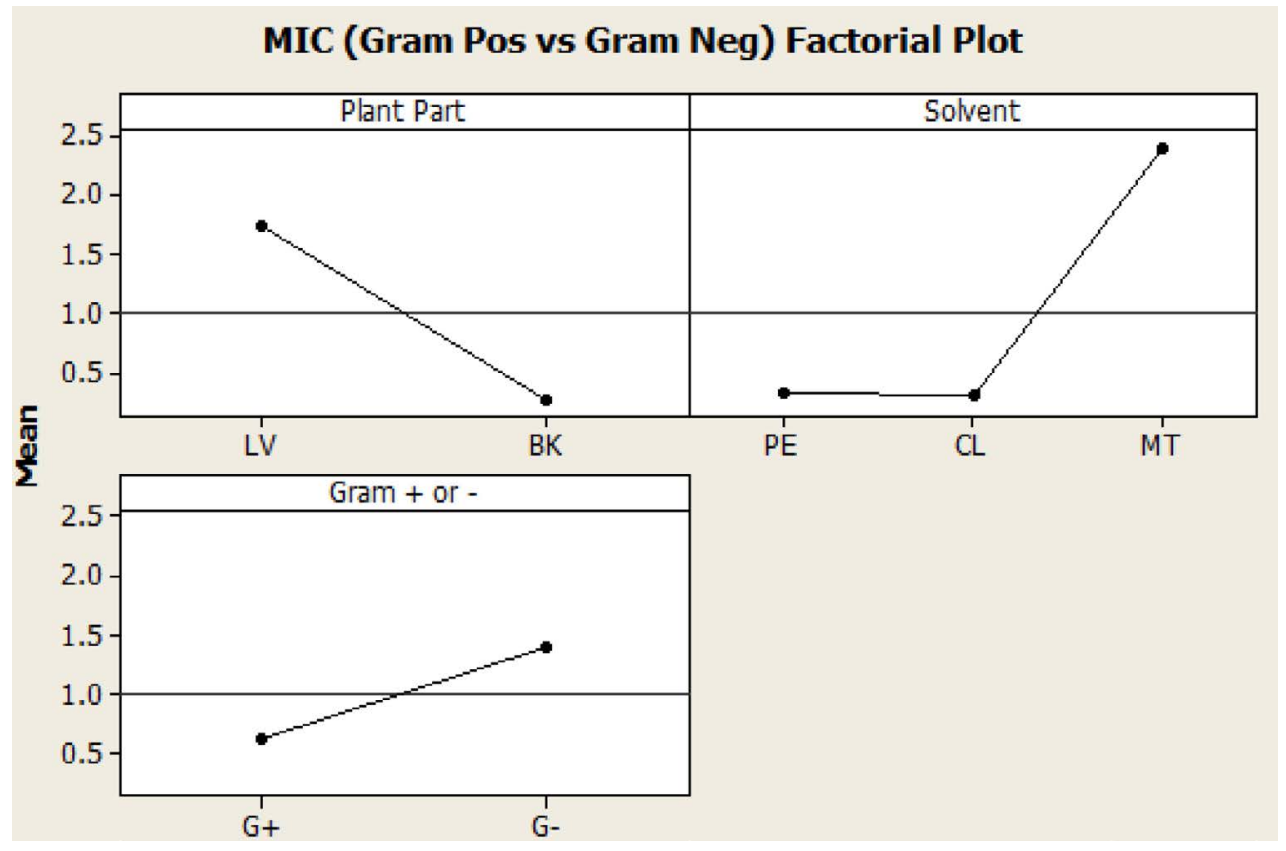

Fig. 5. Plot of multifactorial ANOVA analysis of MIC comparing Gram-positive and Gram-negative organisms 


\section{CONCLUSION}

The leaves and barks were collected from Selangor, Malaysia and extraction was done using different solvents by soxhlet apparatus method. The maximum yield was found when methanol was used as solvent followed by petroleum ether and chloroform. These crude extracts were further diluted to different concentrations for evaluation of antibacterial properties against various gram positive (Staphylococcus aureus, Staphylococcus epidermidis, Streptococcus pyogenes gram) and negative bacteria (Escherichia coli, Klebsiella pneumoniae and Pseudomonas aueroginosa). The antibacterial activity of these extracts was determined by agar well diffusion method, microdilution method. The least MIC concentration of extracts were further carried to determine Minimum bactericidal activity. From this study it was found that the chloroform extract of Rhizophora stylosa was showing the strongest activity against the selected bacteria, followed by petroleum ether and methanol. Since these extracts were predicted to be potent against various gram positive and gram negative bacteria, they can be used a broad spectrum antimicrobial in treating several bacterial diseases.

\section{ACKNOWLEDGMENTS}

None.

\section{CONFLICTS OF INTEREST}

The authors declare that there are no conflicts of interest.

\section{AUTHORS' CONTRIBUTION}

All authors have made substantial, direct and intellectual contribution to the work and approved it for publication.

\section{FUNDING}

None.

\section{DATA AVAILABILITY}

All datasets generated or analyzed during this study are included in the manuscript.

\section{ETHICS STATEMENT}

This article does not contain any studies with human participants or animals performed by any of the authors.

\section{REFERENCES}

1. Jacoby T.S., Kuchenbecker R.S., Dos Santos R.P., Magedanz L., Guzatto P., Moreira L.B. Impact of hospital-wide infection rate, invasive procedures use and antimicrobial consumption on bacterial resistance inside an intensive care unit. J. Hos Infect 2010; 75: 23-27.

2. Fonkwo P.N. Pricing infectious disease: the economic and health implications of infectious diseases. EMBO reports, 2008; 9: 13-17

3. Sasidharan S., Prema B., Yoga L.L. Antimicrobial drug resistance of Staphylococcus aureus in dairy products. Asian Pac. J. Trop. Biomed., 2011; 1(2): 130-132.

4. Saad S., Taher M., Susanti D., Qaralleh H., Rahim N.A.B.A. Antimicrobial activity of mangrove plant (Lumnitzera littorea). Asian Pacific journal of tropical medicine, 2011; 4(7): 523-525.

5. Saad S., Taher M., Susanti D., Qaralleh H., Awang A.F.I.B. In vitro antimicrobial activity of mangrove plant Sonneratia alba. Asian Pacific journal of tropical biomedicine, 2012: 2(6):427-429.

6. Nasir H.M., and Yusmah S.M.Y. 'Distribution of Rhizophora stylosa in Peninsular Malaysia', Journal of Tropical Forest Science, 2007; 19(1): 57-60.

7. Burkill, I.H. 'A Dictionary of Economic Products of the Malay Peninsula', Ministry of Agriculture and Cooperative, Kuala Lumpur, 1996.

8. Jantan I. 'Medicinal Plant Research in Malaysia: Scientific Interests and Advances', Jurnal Sains Kesihatan Malaysia, 2004; 2(2): 27 - 46.

9. Patra JK, \& Thatoi HN. Metabolic diversity and bioactivity screening of mangrove plants: a review. Acta Physiologiae Plantarum, 2011; 33(4): 1051-1061.

10. Bhimba B.V., Meenupriya J., Joel E.L., Naveena D.E, Kumar S, \& Thangaraj M. Antibacterial activity and characterization of secondary metabolites isolated from mangrove plant Avicennia officinalis. Asian Pacific Journal of Tropical Medicine, 2010; 3(7): 544-546.

11. Ncube N.S., Afolayan A.J., \& Okoh A.I. Assessment techniques of antimicrobial properties of natural compounds of plant origin: current methods and future trends. African journal of biotechnology, 2008; 7(12).

12. Bandaranayake W.M. Bioactivities, bioactive compounds and chemical constituents of mangrove plants. Wetlands ecology and management, 2002; 10(6): 421-452.

13. Premanathan M., Kathiresan K., Yamamoto N., Nakashima $\mathrm{H}$. In vitro anti-human immuno-deficiency virus activity of poly-saccharide from Rhizophora mucronata Poir. Bioscience, bio-technology, and biochemistry, 1999; 63(7): 1187-1191.

14. Premanathan M., Arakaki R., Izumi H., Kathiresan K., Nakano M., Yamamoto N., Nakashima H. Antiviral properties of a mangrove plant, Rhizophora apiculata Blume, against human immunodeficiency virus. Antiviral Research, 1999; 44(2): 113-122.

15. Uddin S.J., Nahar L., Shilpi J.A., Shoeb M., Borkowski T., Gibbons S., Sarker S.D. Gedunin, a limonoid from Xylocarpus granatum, inhibits the growth of CaCo 2 colon cancer cell line in vitro. Phytotherapy 
Research, 2007; 21(8): 757-761.

16. Masuda T., Yonemori S., Oyama Y., Takeda Y., Tanaka T., Andoh T., Nakata M. Evaluation of the antioxidant activity of environmental plants: activity of the leaf extracts from seashore plants. Journal of Agricultural and Food chemistry, 1999; 47(4): 1749-1754.

17. Konishi T., Takasaki M., Tokuda H., Kiyosawa S., Konoshima T. Anti-tumor-promoting activity of diterpenes from Excoecaria agallocha. Biological and Pharmaceutical Bulletin, 1998; 21(9): 993-996.

18. Nathan S.S., Kalaivani K., Murugan K. Effects of neem limonoids on the malaria vector Anopheles stephensi Liston (Diptera: Culicidae). Acta tropica, 2005; 96(1): 47-55.

19. Omar S., Zhang J., MacKinnon S.A., Leaman D., Durst T., Philogene B.J.R., Pezzuto, J.M. Traditionally-used antimalarials from the Meliaceae. Current topics in medicinal chemistry, 2003; 3(2): 133-139.

20. Jun W., Qiang X., Jing X., Min Y.L., Jian Y.P., Mei-hua Y. Natural products from true mangrove flora: source, chemistry and bioactivities. Nat Prod Rep. 2008; 25: 955-981

21. Choudhury S., Sree A., Mukherjee S.C., Pattnaik P., Bapuji M. In vitro antibacterial activity of extracts of selected marine algae and mangroves against fish pathogens. Asian fisheries science, 2005; 18(3/4): 285.

22. Caceres A., Lopez B., Juarez X., del Aguila J., Garcia S. 'Plants used in Guatemala for the treatment of dermatophytic infections', evaluation of antifungal activity of seven American plants', Journal of Ethnopharmacology, 1993; 40: $207-213$.

23. Melchor G., Amenteros M., Fernandez O., Linares E., and Fragas L. 'Antibacterial activity of Rhizophora mangle barks', Fitoterapia, 2001;72: 689-691.

24. Marrero E., Sanchez J., de Amas E., Escobar A., Melchor
G., Abad M., Bermejo P., Villar M., Megias J., Alcaraz M.J. 'COX-2 and SPLA2 inhibitory activity of aqueous extracts and polyphenols of Rhizophora mangle (red mangrove)', Fitoterapia, 2006; 77: 313 - 315.

25. Berenguer B., Sanchez L., Quilez A., Lopez-Barriero M., de Haro O., Galvez J., Martin M.J. 'Protective and antioxidant effects of Rhizophora mangle L. against NSAID- induced gastric ulcers', Journal of Ethnopharmacology, 2006; 103: $194-200$.

26. Laphookhieo S., Karalai C., Ponglimanont C. New sesquiterpenoid and triterpenoids from the fruits of Rhizophora mucronata. Chemical and pharmaceutical bulletin, 2004; 52(7): 883-885.

27. Fernandez O., Capdevila J.Z., Dalla G., Melchor G. 'Efficacy of Rhizophora mangle aqueous bark extract in the healing of open surgical wounds', Fitoterapia, 2002; 73: $564-568$.

28. Negi P., Jayaprakasha G. Antibacterial activity of grapefruit (Citrus paradisi) peel extracts. European Food Research and Technology, 2001; 213(6): 484-487.

29. Baron E.J., Peterson L.R., Finegold S.M. Bailey and Scott's Diagnostic Microbiology, 9th edition, the C.V Mosby company, 1994; 333-351

30. Saeed S., Tariq P. Antibacterial activities of Mentha piperita, Pisum sativum and Momordica charantia. Pakistan Journal of Botany, 2005; 37(4): 997.

31. Lim S.H., Darah I., Jain K. Antimicrobial activities of tannins extracted from Rhizophora apiculata barks. Journal of Tropical Forest Science, 2006; 59-65.

32. Courtois E.A., Baraloto C., Paine C.E.T., Petronelli P., Blandinieres P., Stien D., Houel E., Bessiere J., Chave J. 'Differences in volatile terpene composition between the bark and leaves of tropical tree species', Phytochemistry, 2012; 82: 81-88. 